\title{
ELEMENTAL ANALYSIS OF CULINARY HERBS AND SPICES BY ICP OES: CLASSIFICATION BY CHEMOMETRICS
}

\author{
ALEKSANDRA N. PAVLOVIĆca, *, JELENA M. MRMOŠANINa, \\ SNEŽANA Č. JOVANOVIĆa, SNEŽANA S. MITIĆa, SNEŽANA B. TOŠIĆa, \\ JOVANA N. KRSTIĆb and GORDANA S. STOJANOVIĆa
}

\begin{abstract}
The inductively coupled plasma optical emission spectrometry method (ICP OES) was optimized and validated for the quantification of 21 elements in 88 samples of 23 types of culinary herbs and spices. All analyzed samples were low in $\mathrm{Na}$, but rich in $\mathrm{Ca}, \mathrm{K}$ and $\mathrm{P}$. Among the microelements, the most abundant was Fe, followed by $\mathrm{Cu}, \mathrm{Zn}, \mathrm{Cr}$, and Se. The concentrations of toxic elements $(\mathrm{Cd}$ and $\mathrm{Pb}$ ) were below the permissible limits given by the World Health Organisation (WHO). Chemometrics was performed by the principal component analysis (PCA) and cluster analysis (CA). PCA generated two principal components that explained $43.82 \%$ of the total variance in the data and all samples were classified into six groups based on the element content. Also, PCA and CA allowed the differentiation and classification of culinary herbs and spices based on the concentration of five major elements.
\end{abstract}

Keywords: culinary herbs, spices, macro and microelements, ICP OES, chemometrics, classification

\section{INTRODUCTION}

Spices have been an irreplaceable part of traditional and modern cuisines since ancient times. Herbs are plants with aromatic leaves and represent a subset of spices [1]. Not only do spices give a specific flavour to food, but they also have a beneficial effect on human health. In a study conducted by Naveed et al. [2], essential oils from four Pakistani spices

\footnotetext{
a University of Niš, Faculty of Sciences and Mathematics, Department of Chemistry, Višegradska 33, P.O. Box 224, 18000 Niš, Serbia

${ }^{b}$ University of Union Nikola Tesla, Faculty of Applied Science, Department of Contemporary Food Technology, Dušana Popovića 22a, 18000 Niš, Serbia.

*Corresponding author aleksandra.pavlovic@pmf.edu.rs
} 
ALEKSANDRA N. PAVLOVIĆ, JELENA M. MRMOŠANIN, SNEŽANA Č. JOVANOVIĆ, SNEŽANA S. MITIĆ, SNEŽANA B. TOŠIĆ, JOVANA N. KRSTIĆ, GORDANA S. STOJANOVIĆ

cumin, cinnamon, cardamom and clove showed the antibacterial activity against multi-drug resistant bacteria: S. typhi, S. paratyphi, E. coli, S. aureus, $P$. fluorescens and $B$. licheniformis. El-Ghorab et al. [3] pointed out the antioxidant properties of ginger and cumin. The use of essential oils and extracts from spices as preservatives in food protection has also been described [4, 5]. Sgorbini et al. [6] characterized and quantified biologically active markers in some herbs and species (clove, American peppertree, black pepper, white pepper, rosemary, sage and thyme) using separative (HS-SPME-GC-MS) and non-separative (HS-SPME-MS) approaches. They used aromatic markers, eugenol for cloves, carvacrol and thyme for thyme, and thujones for saga which were directly quantified on the solid matrix through the multiple headspace extraction-HS-SPME. Paleari et al. [7] characterized spices and aromatic herbs using GC/MS. They separated components which came from spices/aromatic herbs from the others which came from phenomena due to lipolytic endoenzymatic processes.

Apart from the importance of the organic components, the importance of major and trace elements in spices must not be neglected. The results obtained by Khan et al. [8] indicated that the essential trace elements that were found in aromatic spices have a good nutritional contribution. In contrast, the concentrations of toxic elements ( $\mathrm{As}, \mathrm{Cd}, \mathrm{Pb}$ ) were low and did not pose a threat to human health. Ghanjaoui et al. [9] have developed and validated the inductively coupled plasma optical emission spectrometry (ICP OES) method for the determination of trace elements in basil powder samples from Spain and Morocco. In a study conducted by Tahri et al. [10], 14 elements were determined by inductively coupled plasma atomic emission spectrometry (ICP AES) in rosemary samples collected in eastern Morocco. Özcan and Akbulut [11] have estimated the content of major and minor elements in medicinal and aromatic plants grown in Turkey which are used as spices, condiments and herbal tea by ICP AES, concluding that mineral content varied significantly depending on the species and location of the plant, while the content of heavy metals was very low in all of the samples. Kumaravel and Alagusundaram [12] reported 15 trace elements in five Indian spices, with the absence of $\mathrm{As}$ and $\mathrm{Hg}$ in all of the samples.

However, Abou-Arab and Abou Donia [13] noted that heavy metals present in some spices exceeded the permissible levels, which could be a consequence of the use of contaminated irrigation water, the addition of some fertilizers and herbicides, or the contamination from traffic. The mineral and trace elements content were determined in culinary herbs and spices in many studies. Some of these studies deal with the determination of a small number of elements in a specific type of fresh herbs or spices. Also, before any chemometric technique can be used, it is important to ensure that 
accurate analytical data are being obtained since the conclusions drawn from chemometric techniques can only be as reliable as the data. In this study, all samples were analysed under analytical control with the optimization of the operating parameters of the instrument and with the analysis of a certified reference material. Based on the lack of comprehensive studies of all wellknown macro and microelements involving large number of culinary herb and spice samples, the aim of this work was to determine macro and microelements (Al, B, Ba, Be, Ca, Cd, Co, Cr, Cu, Fe, K, Mg, Mn, Na, Ni, P, $\mathrm{Pb}, \mathrm{Se}, \mathrm{Si}, \mathrm{V}, \mathrm{Zn}$ ) in 88 commercially available samples of culinary herbs and spices after the optimization and validation of the ICP OES method, as well as their classification using the principal component analysis (PCA) and cluster analysis (CA).

\section{RESULTS AND DISCUSSION}

\section{Optimization of the Method}

According to Mermet [14], the Mg II/Mg I line intensity ratio higher than 10 was selected to evaluate ICP operating conditions and the plasma robustness. The highest $\mathrm{Mg}$ II/Mg I ratio was obtained for RF power of 1150 $W$ and nebulizer gas flow of $0.5 \mathrm{~L} / \mathrm{min}$. As in previous works [15, 16], the results showed a higher $\mathrm{Mg} \mathrm{II/Mg} \mathrm{I} \mathrm{ratio} \mathrm{for} \mathrm{the} \mathrm{radially} \mathrm{viewed} \mathrm{configuration}$ (Table S1).

A final selection of wavelength lines was taken into consideration after the study of ratio slope cal $_{\text {slope }}$ sam as well as the accuracy obtained for each line and spectral interferences. As can be seen in Table 1 the slopes of both kinds of lines were statistically comparable, which indicates the lack of matrix effects. ME data up to $7.6 \%$ indicates that the method of evaluation of the matrix effect generates reliable results.

\section{Validation of the Method}

The accuracy of the method was checked by analyzing the SRM. The recovery percentages for all elements were in the range $91-105 \%$ except for $\mathrm{Na}, \mathrm{Cd}, \mathrm{Pb}$, Se and $\mathrm{Si}$ which were $<91 \%$. The percent coefficient of variation (CV\%) obtained for the precision evaluation for all analyte elements was ranged from $1.7 \%$ for $\mathrm{Ca}$ to $14.9 \%$ for $\mathrm{Cr}$. Nevertheless, in all cases, the accuracy and precision were within the acceptable recoveries and $\mathrm{CV}$ percentages obtained from the Horwitz function [17-19] and the AOAC PeerVerified Methods (PVM) program on the analyte level [20]. 
ALEKSANDRA N. PAVLOVIĆ, JELENA M. MRMOŠANIN, SNEŽANA Č. JOVANOVIĆ, SNEŽANA S. MITIĆ, SNEŽANA B. TOŠIĆ, JOVANA N. KRSTIĆ, GORDANA S. STOJANOVIĆ

Table 1. The analyte line selected with the ratio slope cal $_{\text {slope }}$ sam and matrix effect $(\mathrm{ME})$, as well as coefficient of determination $\left(\mathrm{R}^{2}\right), \mathrm{LOD}$ and $\mathrm{LOQ}$ of the calibration for each element determination

\begin{tabular}{|c|c|c|c|c|c|c|c|}
\hline Element $^{\text {Wavelength }}$ & $\begin{array}{c}\text { Plasma view } \\
(\mathrm{nm})\end{array}$ & Slope $_{\text {cal/Slope }}$ sam & $\begin{array}{c}\mathrm{ME} \\
(\%)\end{array}$ & $\mathrm{R}^{2}$ & $\begin{array}{c}\mathrm{LOD} \\
(\mathrm{ng} / \mathrm{g})\end{array}$ & $\begin{array}{c}\mathrm{LOQ} \\
(\mathrm{ng} / \mathrm{g})\end{array}$ \\
\hline $\mathrm{Al}$ & 309.271 & axial & 0.976 & -2.4 & 0.9990 & 77.5 & 260 \\
\hline $\mathrm{B}$ & 249.773 & axial & 1.013 & 1.3 & 0.9982 & 8.00 & 26.6 \\
\hline $\mathrm{Ba}$ & 455.403 & axial & 0.981 & -1.9 & 1 & 0.50 & 1.90 \\
\hline $\mathrm{Be}$ & 234.861 & axial & 0.968 & -3.2 & 0.9998 & 0.80 & 2.40 \\
\hline $\mathrm{Ca}$ & 393.366 & radial & ${ }^{\mathrm{a}}$ & ${ }^{\mathrm{a}}$ & 0.9984 & 0.10 & 0.50 \\
\hline $\mathrm{Cd}$ & 226.502 & axial & 1.019 & 1.9 & 1 & 2.40 & 7.80 \\
\hline $\mathrm{Co}$ & 228.616 & axial & 0.971 & -2.9 & 1 & 4.10 & 13.6 \\
\hline $\mathrm{Cr}$ & 283.563 & axial & 0.952 & -4.8 & 0.9996 & 7.80 & 25.9 \\
\hline $\mathrm{Cu}$ & 324.754 & axial & 0.988 & -1.2 & 1 & 7.60 & 25.5 \\
\hline $\mathrm{Fe}$ & 259.940 & axial & 1.009 & 0.9 & 1 & 7.50 & 25.1 \\
\hline $\mathrm{K}$ & 766.490 & radial & ${ }^{a}$ & ${ }^{a}$ & 0.9990 & 6.60 & 22.1 \\
\hline $\mathrm{Mg}$ & 279.553 & radial & ${ }^{a}$ & ${ }^{a}$ & 0.9990 & 0.20 & 0.60 \\
\hline $\mathrm{Mn}$ & 257.610 & axial & 1.023 & 2.3 & 1 & 1.20 & 4.40 \\
\hline $\mathrm{Na}$ & 589.592 & radial & ${ }^{a}$ & ${ }^{a}$ & 1 & 0.10 & 0.50 \\
\hline $\mathrm{Ni}$ & 221.647 & axial & 1.054 & 5.4 & 0.9996 & 7.40 & 25.0 \\
\hline $\mathrm{P}$ & 213.618 & radial & ${ }^{a}$ & ${ }^{a}$ & 1 & 49.0 & 163 \\
\hline $\mathrm{Pb}$ & 220.353 & axial & 1.063 & 6.3 & 1 & 25.4 & 84.5 \\
\hline $\mathrm{Se}$ & 196.090 & axial & 1.049 & 4.9 & 1 & 41.8 & 139 \\
\hline $\mathrm{Si}$ & 251.611 & axial & 0.924 & -7.6 & 0.9974 & 20.6 & 68.8 \\
\hline $\mathrm{V}$ & 309.311 & axial & 0.988 & -1.2 & 1 & 7.40 & 24.8 \\
\hline $\mathrm{Zn}$ & 213.856 & axial & 1.044 & 4.4 & 0.9996 & 1.50 & 4.80 \\
\hline & & & & & & & \\
\hline
\end{tabular}

alt was not necessary to optimize slope cal $_{\text {slope }}$ sam and matrix effect for the major elements $\mathrm{Ca}, \mathrm{K}, \mathrm{Mg}, \mathrm{P}$ and $\mathrm{Na}$ because of their relatively high concentration in the samples

\section{Macro and Microelements in Culinary Herbs and Spice Samples}

The results of the elemental analysis of spice and herb samples (Supplementary materials) indicate that $\mathrm{Ca}$ and $\mathrm{K}$ were the most abundant macro elements, followed by $\mathrm{P}, \mathrm{Mg}$, and $\mathrm{Na}$. The mean concentrations of $\mathrm{Ca}$ 
are ranged from $0.6 \mathrm{mg} / \mathrm{g}$ in garlic to $17.4 \mathrm{mg} / \mathrm{g}$ in lovage, while the mean concentrations of $\mathrm{K}$ are ranged from $1.45 \mathrm{mg} / \mathrm{g}$ in cinnamon to $10.9 \mathrm{mg} / \mathrm{g}$ in parsley. The highest mean concentrations of $\mathrm{P}$ and $\mathrm{Mg}$ were found in white mustard and celery yielding $7.83 \mathrm{mg} / \mathrm{g}$ and $4.75 \mathrm{mg} / \mathrm{g}$, respectively.

The lowest mean concentrations of $\mathrm{P}$ and $\mathrm{Mg}$ were found in cinnamon yielding $0.570 \mathrm{mg} / \mathrm{g}$ and $0.381 \mathrm{mg} / \mathrm{g}$, respectively. The mean concentration of $\mathrm{Na}$ varied and ranged from $2.85 \mu \mathrm{g} / \mathrm{g}$ in chive to $138 \mu \mathrm{g} / \mathrm{g}$ in clove. All analyzed samples are low in $\mathrm{Na}$, but rich in $\mathrm{Ca}, \mathrm{K}$ and $\mathrm{P}$. The macro element contents are in good agreement with the reported data on macro element content of spices and condiments used in Turkey, but lower for $\mathrm{Na}$ (1.16$16.45 \mathrm{mg} / \mathrm{g} \mathrm{Ca}, 3.57-27.67 \mathrm{mg} / \mathrm{g} \mathrm{K}, 0.48-4.31 \mathrm{mg} / \mathrm{g} \mathrm{Mg}, 0.44-9.37 \mathrm{mg} / \mathrm{g} \mathrm{P}$, and $1.1-20.91 \mathrm{mg} / \mathrm{g} \mathrm{Na}$ ) [11].

Among the essential elements, Fe was the most abundant, followed by $\mathrm{Cu}, \mathrm{Zn}, \mathrm{Cr}$ and $\mathrm{Se}$. The results obtained for these metal concentrations are in accordance with the literature data for aromatic spices [8] and medicinal herbs [21]. The mean content of Se, which has a role in the antioxidant defence system of the body, ranged from n.d. in thyme, basil, dill, parsnip, nutmeg, garlic, chive, rosemary and caraway to $0.255 \mu \mathrm{g} / \mathrm{g}$ in ginger. According to Aras and Ataman [22], the differences in the content of Se can be a consequence of the soil composition in which the food is grown.

The manganese, cobalt, silicon, nickel, boron and vanadium were detected in all samples and levels were among 9.51-249 $\mu \mathrm{g} / \mathrm{g}, 0.076-0.813$ $\mu \mathrm{g} / \mathrm{g}, 7.68-936 \mu \mathrm{g} / \mathrm{g}, 0.843-4.89 \mu \mathrm{g} / \mathrm{g}, 2.57-30.1 \mu \mathrm{g} / \mathrm{g}$ and $1.05-19.9 \mu \mathrm{g} / \mathrm{g}$, respectively. Boron is essential for plants and tends to accumulate in plant tissues. Rich sources of $B$ are nuts, leafy vegetables and fruits [22]. According to WHO [23] the mean daily intake of $B$ for adults is $1.2 \mathrm{mg}$ per day.

In this study, the levels of $\mathrm{Be}$ and $\mathrm{Ba}$ were in the range of n.d.-0.077 $\mu \mathrm{g} / \mathrm{g}$ and 3.98-314 $\mu \mathrm{g} / \mathrm{g}$, respectively. Ba was detected in all samples. When grown in Ba-rich soils, plants can accumulate higher levels of $\mathrm{Ba}$, which further increases the potential dietary Ba intakes [24].

Lead and cadmium have no essential function in plants and at high concentrations are toxic for plants and animals as well as for humans. The uptake of $\mathrm{Pb}$ and $\mathrm{Cd}$ by plant roots depends on the concentration, the oxidation state of this metal in the solution, and the physical-chemical characteristics of the soils such as $\mathrm{pH}$ content of clay, minerals, and organic matter $[25,26]$. The Joint FAO/WHO [27] provisionally recommends that the weekly intake of lead should not exceed $25 \mu \mathrm{g} / \mathrm{kg}$ of body weight per week and $7 \mu \mathrm{g} / \mathrm{kg}$ of body weight should be regarded, provisionally, as the maximum tolerable weekly intake of $\mathrm{Cd}$. The results obtained for $\mathrm{Pb}(0.38-$ $2.67 \mu \mathrm{g} / \mathrm{g})$ and $\mathrm{Cd}(0.032-0.221 \mu \mathrm{g} / \mathrm{g})$ are in accordance with the literature data $[8,12]$ and below the limits given by the FAO/WHO [27]. 
ALEKSANDRA N. PAVLOVIĆ, JELENA M. MRMOŠANIN, SNEŽANA Č. JOVANOVIĆ, SNEŽANA S. MITIĆ, SNEŽANA B. TOŠIĆ, JOVANA N. KRSTIĆ, GORDANA S. STOJANOVIĆ

\section{Pearson's Correlation Analysis}

In this study, the correlation analysis was performed at a 0.05 probability level to evaluate the relationship among the element concentrations. The results are included in Supplementary material (Table S2 (Supplementary material). According to Cohen, a strong correlation exists when $r \geq|0.5|$ [28]. Among the elements, $\mathrm{K}$ showed a positive correlation with $\mathrm{Ca}, \mathrm{Mg}, \mathrm{B}$ and $\mathrm{V}$; $\mathrm{P}$ with $\mathrm{Zn}$; $\mathrm{Al}$ with $\mathrm{Ni}$ and $\mathrm{Si} ; \mathrm{Cr}$ with $\mathrm{Si}$; and $\mathrm{Fe}$ with $\mathrm{Ni}, \mathrm{Pb}$ and $\mathrm{Si}$.

The elements showing the significant positive correlation are $\mathrm{Fe}$ and $\mathrm{Si}(0.80), \mathrm{Al}$ and $\mathrm{Si}(0.74)$ and $\mathrm{Fe}$ and $\mathrm{Pb}(0.73)$. Of all macro elements $\mathrm{Mg}$ shows a good correlation with $\mathrm{V}(0.84), \mathrm{B}(0.74)$ and $\mathrm{Ca}(0.71)$. It is assumed that a good correlation indicates a similar origin of the elements in the tested plants [21]. There were some correlations which were very close to 0 , for example, $\mathrm{Na}$ with $\mathrm{Pb}, \mathrm{K}, \mathrm{Mg}, \mathrm{Cu}, \mathrm{Zn}, \mathrm{B}$, Be with $\mathrm{Al}, \mathrm{Cd}$ with $\mathrm{Cr}, \mathrm{Ni}$ and $\mathrm{Se}$, which indicates weak relations between these elements.

\section{Chemometric Data Processing}

PCA was used for extracting the data from variables and reducing the number of inter-correlated variables to uncorrelated variables (PC), thereby allowing a more accurate estimate [29]. The principal components are rotated so that the total sum of squares of the loading along each axis is maximised [30]. For this chemometric calculation, a data matrix $(21 \times 88)$ was constructed using 88 samples as rows and content of 21 metals as columns. Six principal components with eigenvalues $>1$, as suggested by the Kaiser criterion [30], were extracted by PCA. These six components explained about $74.3 \%$ of the variation in the data. The first component (PC1) had the highest eigenvalue of 5.44 and explained $25.89 \%$ of the total variance. The eigenvalue of the second component (PC2) was 3.76 and explained $17.93 \%$ of the total variance in data. As the first two factors explain $43.82 \%$ of the total variations and the contributions of the third, fourth, fifth and sixth are considerably lower, PC1 and PC2 were used for a further analysis. Figure 1 shows the score plot for all 88 samples. The first group, in the lower right quadrant, consists of spices from the Lauraceae family (cinnamon and bay laurel). This group is extracted by the high concentrations of $\mathrm{Cd}$ and $\mathrm{Be}$ (Figure 2). The second group, the Zingiberaceae family (turmeric and ginger), is located on the negative side of PC1 and the negative side of PC2. This group is extracted by the high concentrations of $\mathrm{Cr}$, Si and $\mathrm{Pb}$. Next to these elements, $\mathrm{Al}, \mathrm{Ni}$, and $\mathrm{Fe}$ are grouped in the lower left quadrant with the significant positive correlation between $\mathrm{Fe}$ and $\mathrm{Si}(0.80), \mathrm{Al}$ and $\mathrm{Si}(0.74)$ and $\mathrm{Fe}$ and $\mathrm{Pb}(0.73)$. Al and $\mathrm{Si}$ are highly present in the soil. Silicon gives strength to the cell wall and increases the resistance of the plant to insects and fungal diseases, while the available Al, despite its toxicity in plants [31], in some species such as Camellia sinensis and Melastoma malabathricum 
has a beneficial effect on plant growth [32]. The third group consists of spices from the Lamiaceae family (basil, one sample of marjoram, and one sample of oregano) is located in the negative side of PC1, and in the positive side of $\mathrm{PC} 2$. This group is extracted by the high concentrations of $\mathrm{V}$ and $\mathrm{Zn}$, and relatively high concentrations of macroelements $\mathrm{K}, \mathrm{Ca}$, and $\mathrm{Mg}$ (Figure 2). Potassium and phosphorus (negative loadings on PC1 and positive loadings on PC2) in some spices probably originate from artificial fertilizers NPK [33]. Potassium, phosphorus and magnesium are grouped in the same quarter as the elements necessary for photosynthesis. The fourth group includes spices from the Lamiaceae family (Breckland thyme, thyme, marjoram, oregano, and rosemary) and it is located near zero of PC1 and PC2. The fifth group, Apiaceae (dill, parsley, coriander, caraway, celera, lovage, and parsnip), is between the two groups of Lamiaceae and this group is extracted by the high content of P (Figure 2). The sixth group is Amaryllidaceae (garlic and chive) and it is located on the positive side of PC1 and near zero of PC2. It can be seen that the samples from the Brassicaceae family (white mustard) do not belong to any group. The Brassicaceae family was reported as a hyperaccumulator of $\mathrm{Cd}, \mathrm{Zn}$ and $\mathrm{Ni}[26,34]$.

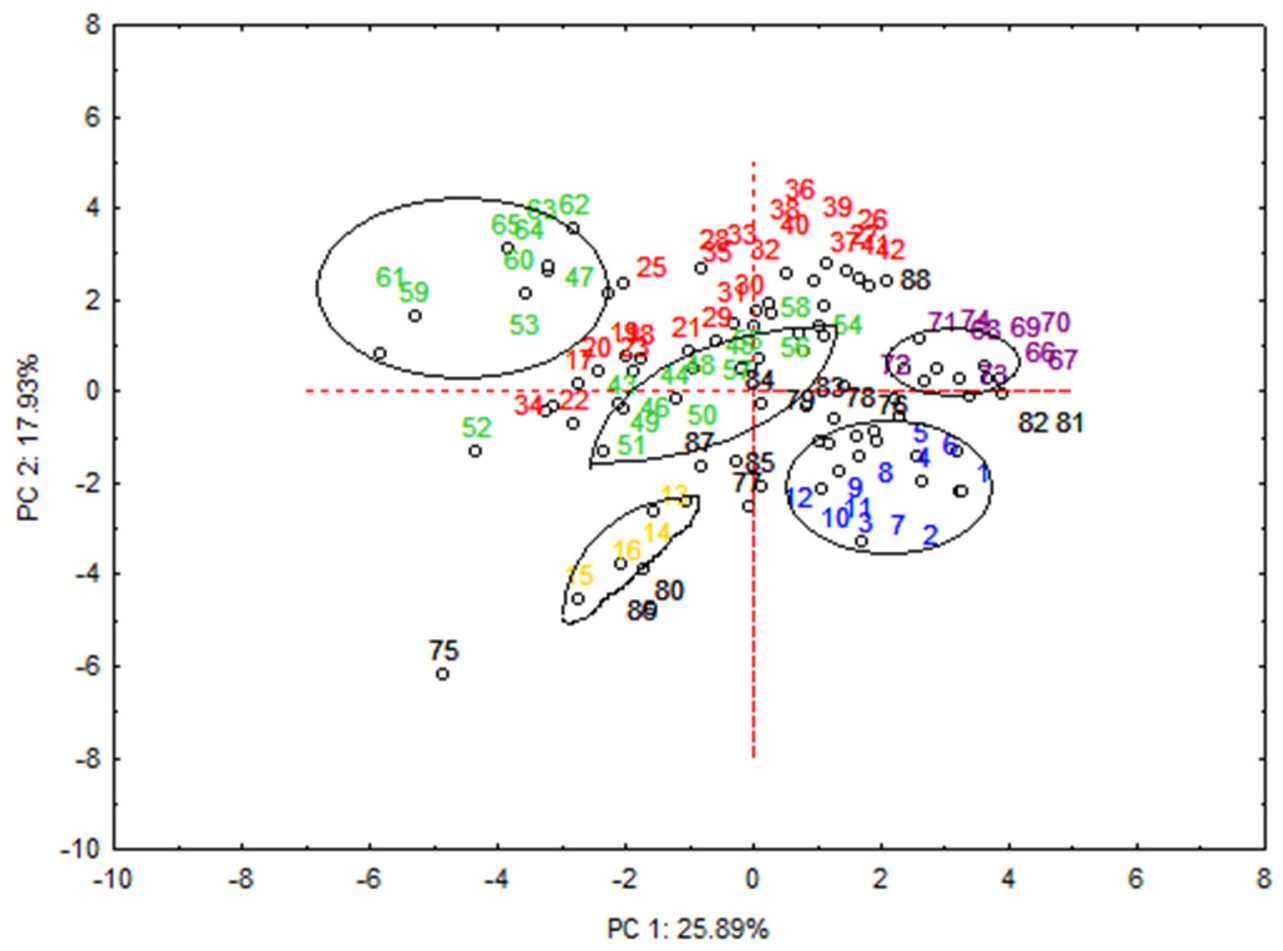

Figure 1. PCA score plot obtained for classification of culinary herbs and spices 
ALEKSANDRA N. PAVLOVIĆ, JELENA M. MRMOŠANIN, SNEŽANA Č. JOVANOVIĆ, SNEŽANA S. MITIĆ, SNEŽANA B. TOŠIĆ, JOVANA N. KRSTIĆ, GORDANA S. STOJANOVIĆ

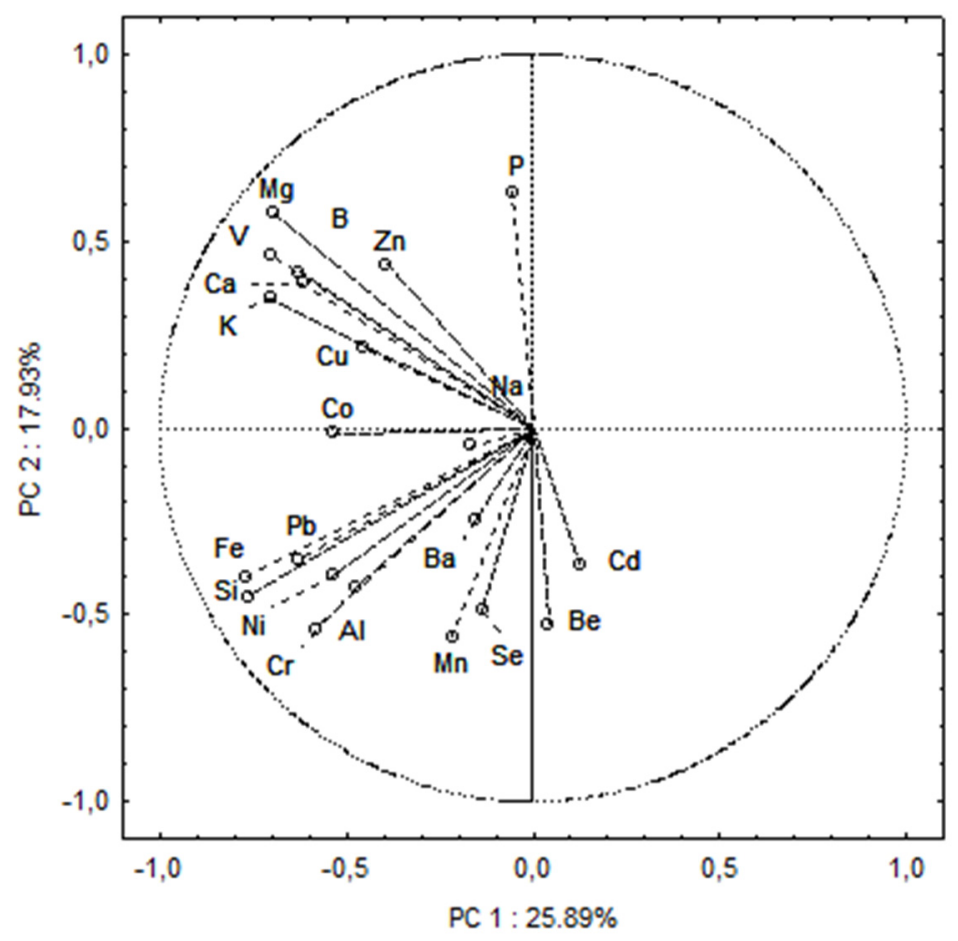

Figure 2. PCA loading plot of the elemental composition of culinary herbs and spices

When macro elements were considered as the elements with bigger loadings on PC1 and PC2, the scores of PC1 and PC2 in Figure 3 indicate that the macro elements affect the separation of the samples. The first and second components reported $48.65 \%$ and $21.58 \%$ variance, respectively. The first two components described $70.23 \%$ variances for all data. From the higher scores of the first principal component, it can be interpreted that the concentrations of $\mathrm{Na}$ on PC1 are higher for the samples from the Myrtaceae family (clove) and are lower for all other samples, the concentrations of $\mathrm{Ca}$ are similar and the concentrations of $\mathrm{Na}$ are high for the samples from the Apiaceae family (parsley, dill), the concentrations of $\mathrm{Mg}$ are higher for the samples from the Apiaceae family (lovage, celery) and the samples from the Lamiaceae family (basil). When the second principal component is interpreted, $\mathrm{P}$ concentrations on the PC2 loadings are higher for samples from the Apiaceae family (coriander, caraway) and for one sample from the Brassicaceae family (white mustard) and they are lower for all other samples. The cinnamon and bay laurel samples from the Lauraceae family have the lowest content of $\mathrm{Mg}$, 
$\mathrm{K}$ and $\mathrm{P}$. The turmeric and ginger samples from the Zingiberaceae family, the parsnip samples from the Apiaceae family, the garlic samples from the Amaryllidaceae family, the black pepper samples from the Piperaceae family and the nutmeg samples from the Myristicaeae family have the lowest content of $\mathrm{Ca}$ and $\mathrm{K}$.

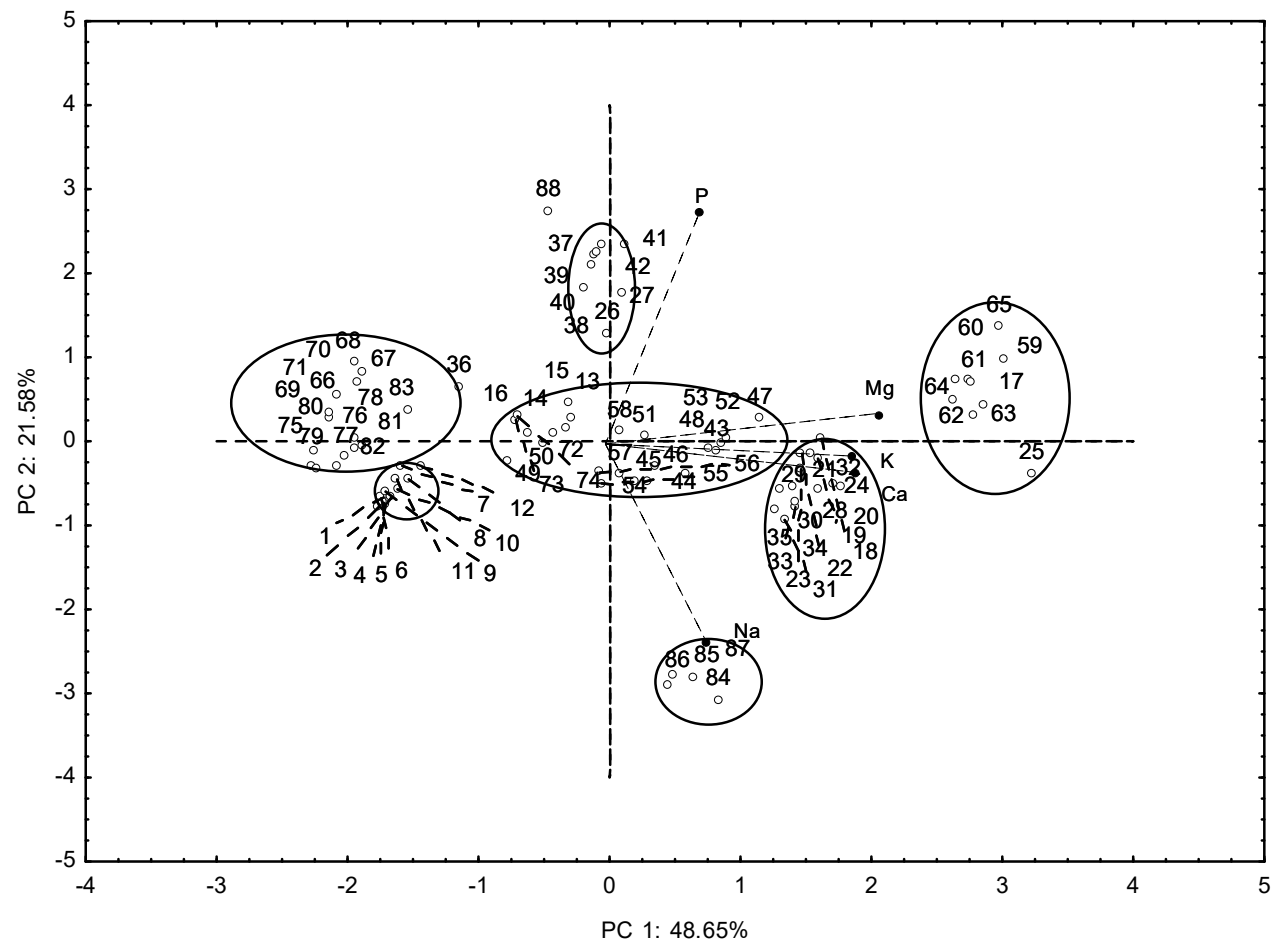

Figure 3. PCA score plot for classification of culinary herbs and spices based on macro element contents

The cluster analysis was performed using the same variables as in PCA, obtaining a second correct classification (Supplementary material) with six clusters. The first cluster on the right consists of samples from the Lauraceae family (cinnamon and bay laurel). The second cluster includes samples from the Amaryllidaceae (garlic), Apiaceae (parsnip), Myristicaceae (nutmeg) and Piperaceae (black paper) family. The third cluster consists of two subclusters. The first subcluster includes the samples from the Myrtaceae family (clove), the second subcluster contains the samples from the Apiaceae family (parsley, dill). The fourth cluster consists of the samples from the Apiaceae (25 celery and 17 lovage) and Lamiaceae (59-65 basil) family. The fifth cluster includes the samples from the Zingiberaceae (turmeric, ginger) Lamiaceae (oregano, Breckland thyme, thyme, marjoram, rosemary), Amaryllidaceae (chive) family. 
ALEKSANDRA N. PAVLOVIĆ, JELENA M. MRMOŠANIN, SNEŽANA Č. JOVANOVIĆ, SNEŽANA S. MITIĆ, SNEŽANA B. TOŠIĆ, JOVANA N. KRSTIĆ, GORDANA S. STOJANOVIĆ

The sixth cluster includes the samples from the Apiaceae family (coriander, caraway). White mustard from the Brassicaceae family is joined to this cluster. Based on the CA results, the samples from the Lamiaceae family are grouped in cluster five, the only base is in cluster four, the Apiaceae family samples are grouped in three clusters (three, four and six) which are next to each other, and this grouping of samples is in accordance with the results obtained from PCA.

\section{CONCLUSIONS}

This study contributes to the analysis of element concentrations in 88 culinary herb and spice samples. All of the analyzed samples were found to be high in $\mathrm{Ca}$ and $\mathrm{K}$ compared to other elements. Among microelements, Fe was the most abundant, followed by $\mathrm{Cu}, \mathrm{Zn}, \mathrm{Cr}$ and Se. The concentrations of toxic elements ( $\mathrm{Pb}$ and $\mathrm{Cd}$ ) were below the limits given by $\mathrm{FAO} / \mathrm{WHO}$ [27]. The correlation analysis showed that strong positive correlations exist between $\mathrm{Fe}$ and $\mathrm{Si}, \mathrm{Al}$ and $\mathrm{Si}$ and $\mathrm{Fe}$ and $\mathrm{Pb}$. Of all macro elements, $\mathrm{Mg}$ showed a good correlation with $\mathrm{V}, \mathrm{B}$ and $\mathrm{Ca}$. The data analysis was done using chemometrics such as PCA and CA. According to PCA, all samples were classified into six groups. The first group consists of the spices from the family of Lauraceae (cinnamon and bay laurel), the second group includes the family of Myrtaceae (clove), the third group consists of the spices from the family of Lamiaceae (basil, Breckland thyme, thyme, marjoram, rosemary, and oregano), the fourth group includes the spices from the family of Apiaceae (dill, parsley, coriander, caraway) and Amaryllidaceae (chive), the fifth group is the Zingiberaceae family (turmeric and ginger) and the sixth group is the Amaryllidaceae family (garlic). The samples from the family of Brassicaceae (white mustard) do not belong to any group. CA confirms the results obtained by PCA. Also, the chemometric analysis allowed the classification of culinary herbs and spices based on the concentation of five major elements. Due to their simplicity, PCA and CA can be useful to classify culinary herbs and spices according to their species.

\section{MATERIALS AND METHODS}

\section{Reagents}

Ultra-scientific (USA) ICP multi-element standard solutions of about $20.00 \pm 0.10 \mathrm{mg} / \mathrm{L}$ were used as a stock solution for calibration. The glass containers used for storing the samples were treated with a $20 \%$ nitric acid and washed with ultra-pure water $0.05 \mu \mathrm{S} / \mathrm{cm}$ (MicroMed high purity water system, TKA Wasseraufbereitungssysteme $\mathrm{GmbH}$ ) to avoid the contamination of the samples with traces of any metals. The nitric acid (65\%) (Merck, Darmstadt, Germany) was of analytical grade. 


\section{Instrumentation}

The entire analysis was carried out on an iCAP 6000 inductively coupled plasma optical emission spectrometer (Thermo Scientific, Cambridge, UK) which uses the Echelle optical design and a charge injection device solidstate detector. The nebulizer was glass concentric. An iTEVA software from Thermo Scientific (Cambridge, UK) was used to collect and analyze the data. The digestion was performed in a microwave digestion system ETHOS 1 (Milestone, Bergamo, Italy).

\section{Samples}

Eighty-eight commercially available samples of twenty-three different culinary herbs and spices were purchased at local markets in Serbia. All samples were bought as pulverized/ground and dried by the manufacturer. No further drying was applied. The English and botanical names of the analyzed culinary herbs and spices are listed in Table 4.

\section{Sample Preparation}

The samples were digested according to Khan et al. [8] with the following modifications: $1 \mathrm{~g}$ of each sample was accurately weighed and then $7 \mathrm{ml}$ concentrated $\mathrm{HNO}_{3}(70 \%)$ and $1 \mathrm{~mL} \mathrm{H}_{2} \mathrm{O}_{2}$ were added and digested using the microwave system. The conditions were as follows: $500 \mathrm{~W}$ at $80{ }^{\circ} \mathrm{C}$ for $5 \mathrm{~min} ; 500 \mathrm{~W}$ at $50{ }^{\circ} \mathrm{C}$ for $5 \mathrm{~min} ; 500 \mathrm{~W}$ at $180^{\circ} \mathrm{C}$ for $10 \mathrm{~min}$, and $0 \mathrm{~W}$ for $30 \mathrm{~min}$ for cooling. After cooling the content of the tubes was transferred to $25 \mathrm{~mL}$ volumetric flask and diluted to $25 \mathrm{~mL}$ with a $0.5 \% \mathrm{HNO}_{3}$. The same procedure was carried out for a blank sample and SRM NCS ZC73036. All samples were analyzed in triplicates.

\section{Optimization of the Method}

Before the metal analysis, the operating parameters were conducted to check the instrument performance. Using a $27.12 \mathrm{MHz} I C P$, RF power, and nebulizer, the argon flow rate was varied under the constant values of other plasma conditions: flush pump-rate $100 \mathrm{~min}^{-1}$, analysis pump-rate 50 $\mathrm{min}^{-1}$, coolant gas flow-rate $12 \mathrm{~L} / \mathrm{min}$, auxiliary gas flow-rate $0.5 \mathrm{~L} / \mathrm{min}$, dualviewed plasma mode (axial/radial) and sample uptake delay of $30 \mathrm{~s}$.

The standard addition method was used to overcome the matrix effect $[35,36]$. A ratio of two elemental signals was used to calculate the matrix effect [37]. The analytic lines were evaluated according to the ratio of the slope of the calibration curve and slope of the standard addition method line (slope cal $_{\text {slope }}$ sam). 
ALEKSANDRA N. PAVLOVIĆ, JELENA M. MRMOŠANIN, SNEŽANA Č. JOVANOVIĆ, SNEŽANA S. MITIĆ, SNEŽANA B. TOŠIĆ, JOVANA N. KRSTIĆ, GORDANA S. STOJANOVIĆ

Table 4. Culinary herbs and spices studied

\begin{tabular}{|c|c|c|c|c|}
\hline No & $\mathrm{n}^{\mathrm{a}}$ & English name & Species & Family \\
\hline $1-6$ & 6 & Cinnamon & Cinnamomum verum J.Presl & Lauraceae \\
\hline $7-12$ & 6 & Bay laurel & Laurus nobilis L. & Lauraceae \\
\hline $13-14$ & 2 & Turmeric & Curcuma longa $\mathrm{L}$. & Zingiberaceae \\
\hline $15-16$ & 2 & Ginger & Zingiber officinale Roscoe & Zingiberaceae \\
\hline 17 & 1 & Lovage & Levistricum officinale W.D.J. Koch & Apiaceae \\
\hline $18-24$ & 7 & Parsley & Petroselinum crispum (Mill.) Fuss & Apiaceae \\
\hline 25 & 1 & Celery & Apium graveolens $\mathrm{L}$. & Apiaceae \\
\hline $26-27$ & 2 & Coriander & Coriandrum sativum $\mathrm{L}$. & Apiaceae \\
\hline $28-35$ & 8 & Dill & Anethum graveolens $\mathrm{L}$. & Apiaceae \\
\hline 36 & 1 & Parsnip & Pastinaca sativa L. & Apiaceae \\
\hline $37-42$ & 6 & Caraway & Carum carvi L. & Apiaceae \\
\hline $43-48$ & 6 & Oregano & Origanum vulgare L. & Lamiaceae \\
\hline $49-50$ & 2 & Breckland thyme & Thymus serpyllum $\mathrm{L}$. & Lamiaceae \\
\hline 51 & 1 & Thy & Thymus vulgaris $\mathrm{L}$. & Lamiaceae \\
\hline $52-53$ & 2 & Marjc & Origanum majorana L. & Lamiaceae \\
\hline $54-58$ & 5 & Rosemary & Rosmarinus officinalis $\mathrm{L}$. & Lamiaceae \\
\hline $59-65$ & 7 & Basil & Ocimum basilicum L. & Lamiaceae \\
\hline $66-71$ & 6 & Garlic & Allium sativum $\mathrm{L}$. & Amaryllidaceae \\
\hline $72-74$ & 3 & Chive & Allium schoenoprasum L. & Amaryllidaceae \\
\hline $75-80$ & 6 & Black pepper & Piper nigrum L. & Piperaceae \\
\hline $81-83$ & 3 & Nutmeg & Myristica fragans Houtt. & Myristicaceae \\
\hline $84-87$ & 4 & Clove & $\begin{array}{c}\text { Syzygium aromaticum L. Merrill } \\
\text { \& Perry }\end{array}$ & Myrtaceae \\
\hline 88 & 1 & White mustard & Sinapis alba L. & Brassicaceae \\
\hline
\end{tabular}

${ }^{a}$ number of samples from each selected spice.

\section{Validation}

The validation process involved the linearity of the calibration curve which was tested from 0 to $5 \mathrm{mg} / \mathrm{kg}$, detection (LOD) and quantification limit (LOQ). Both limits were expressed in ng/g. All calibration curves were prepared with four standard solutions, including the blank. The linearity was assessed by the coefficients of the determinations $\left(R^{2}\right)$ of calibration curves. The certified reference material (green tea), supplied by The China National Analysis Center for Iron and Steel, Beijing, China (NCS ZC73036), was analyzed for the determination of $\mathrm{B}, \mathrm{Ba}, \mathrm{Be}, \mathrm{Ca}, \mathrm{Cd}, \mathrm{Co}, \mathrm{Cr}, \mathrm{Cu}, \mathrm{Fe}, \mathrm{K}, \mathrm{Mg}$, $\mathrm{Mn}, \mathrm{Na}, \mathrm{Ni}, \mathrm{P}, \mathrm{Pb}, \mathrm{Se}, \mathrm{Si}, \mathrm{V}$ and $\mathrm{Zn}$ in order to the check the accuracy of the method. The samples were handled according to the supplier's specifications. 
Supplementary materials containing the standard reference material analysis results and cluster analysis dendrogram can be obtained upon request from the authors.

\section{Data Analysis}

All correlations (Pearson's correlation analysis) and chemometric analyses such as principal component analysis (PCA) and cluster analysis (CA) were performed using Statistica 8.0 (StartSoft, Tusla, Oklahoma, USA). PCA is a chemometric technique used to reduce the dimensionality of large datasets, with an increasing interpretability and minimization of data lost. The new PC variables are linear functions of the origin data. PCA is used to reduce solving an eigenvalue problem [38]. Cluster analysis, also called numerical taxonomy, is a chemometric technique used for grouping similar objects in the same clusters. Cluster analysis examines all relationships between variables and does not differentiate between dependent and independent variables [39]. The chemometric techniques are used to evaluate whether or not there is a relationship between the metal contents in different types of herbs which belong to the same family, as well as for grouping samples based on the metal contents.

\section{ACKNOWLEDGMENTS}

The authors would like to acknowledge financial support from the Ministry of Education, Science and Techology Development of the Republic of Serbia (Agreement No 451-03-68/2020-14-200124).

\section{REFERENCES}

1. The United Nations Industrial Development Organization and Food and Agriculture Organization (UNIDO/FAO), "Spices and essential oils: Postharvest operations indeveloping countries", 2005. Available from: http://www.fao.org/3/a-ad420e.pdf.

2. R. Naveed, I. Hussain, A. Tawab, M. Tariq, M. Rahman, S. Hameed, S. Mahmood, A.B. Siddique, M. Iqbal, BMC Complem. Altern. M., 2013, 13(1), 265.

3. A.H. El-Ghorab, M. Nauman, F.M. Anjum, S. Hussain, M. Nadeem, J. Agric. Food Chem., 2010, 58(14), 8231-8237.

4. L. Hernández-Ochoa, Y.B. Aguirre-Prieto, G.V. Nevárez-Moorillón, N. GutierrezMendez, E. Salas-Muñoz, J. Food Sci. Technol., 2014, 51(5), 957-963. 
ALEKSANDRA N. PAVLOVIĆ, JELENA M. MRMOŠANIN, SNEŽANA Č. JOVANOVIĆ, SNEŽANA S. MITIĆ, SNEŽANA B. TOŠIĆ, JOVANA N. KRSTIĆ, GORDANA S. STOJANOVIĆ

5. N. Celikel, G. Kavas, Czech J. Food Sci., 2008, 26(3),174-181.

6. B. Sgorbini, C. Bicchi, C. Cagliero, C. Cordero, E. Liberto, P. Rubiolo, J. Chromatography, 2015, 1376, 9-17.

7. M.A. Paleari, V.M. Moretti, C. Bersani, G. Beretta, T. Mentasti, Meat Sci., 2004, 67(4), 549-557.

8. N. Khan, J.Y. Choi, E.Y. Nho, N. Jamila, G. Habte, J.H. Hong, I.M. Hwang, K.S. Kim, Food Chem., 2014, 158, 200-206.

9. M.E. Ghanjaoui, M.L. Cervera, M. El Rhazi, M. de la Guardia, Food Chem., 2011, 125,1309-1313.

10. M. Tahri, B. Imelouane, F. Aouinti, H. Amhamdi, A. Elbachiri, Res. Chem. Intermed., 2014, 40, 2651-2658.

11. M. Özcan, M. Akbulut, Food Chem., 2007, 107(2), 852-858.

12. S. Kumaravel, K. Alagusundaram, Orient. J. Chem., 2014, 30(2), 631-636.

13. A.A.K. Abou-Arab, M.A. Abou Donia, J. Agric. Food Chem., 2000, 48(6), $2300-$ 2304.

14. J.M. Mermet, Anal. Chim. Acta, 1991, 250, 85-94.

15. M. Mitić, A. Pavlović, S. Tošić, P. Mašković, D. Kostić, S. Mitić, G. Kocić, J. Mašković, Microchem. J., 2018, 141, 197-203.

16. J.M. Mrmošanin, A.N. Pavlović, J.N. Krstić, S.S. Mitić, S.B. Tošić, M.B. Stojković, R.J. Micić, M.S. Đorđević, J. Food Compost. Anal., 2018, 67, 163-171.

17. W. Horwitz, Anal. Chem., 1982, 54, 67-76.

18. M. Thompson, The amazing Horwitz function. AMC Technical Brief No.17., London, UK: Royal Society of Chemistry, 2004. Available from:

https://www.rsc.org/images/horwitz-function-technical-brief-17_tcm18-214859.pdf.

19. A.G. Gonzalez, M.A. Herrador, Trend. Anal. Chem., 2007, $26(3), 227$.

20. Method Validation Program (OMA/PVM Department), including Appemdix D: Guidelines for collaborative study procedures to validate characteristics of a method of analysis, Rockville, MD, USA: AOAC International, 2000, Available from:http://www.aoac.org/aoac_prod_imis/AOAC_Docs/StandardsDevelopme nt/Collaborative_StudyValidation_Guidelines.pdf.

21. Ş. Tokalioğlu, Food Chem., 2012,134(4), 2504-2508.

22. N.K. Aras, O.Y. Ataman, "Trace element analysis of food and diet", RSC Food Anal Monographs, Cambridge, United Kingdom, The Royal Society of Chemistry, 2006.

23. World Health Organization (WHO), "Boron", Environmental Health Criteria 204: International programme on chemical safety [online]. Geneva, Switzerland, 1998. Available from: http://www.inchem.org/documents/ehc/ehc/ehc204.htm/.

24. World Health Organization (WHO), "Barium and barium compounds", Concise International Chemical Assessment Document 33 [online]. Geneva, Switzerland, 2001. Available from:

https://apps.who.int/iris/bitstream/handle/10665/42398/9241530332.pdf?sequ ence=1/.

25. M. Brokbartold, M. Wischermann, B. Marschner, Water Air Soil Pollut., 2011, 223(1), 199-213. 
26. D.K. Gupta, F.J. Corpas, J.M. Palma, "Heavy metal stress in plants". SpringerVerlag, Berlin Heidelberg, Germany, 2013.

27. Food and Agriculture Organization and World Health Organization (FAO/WHO), "Trace elements in human nutrition and health", International Atomic Energy \& Food and Agriculture Organization of the United Nations Geneva, Geneva, Switzetland, 1996. Available from: https://www.who.int/nutrition/publications/micronutrients/9241561734/en/.

28. J. Cohen, "Statistical power analysis for the behavioral science" $2^{\text {nd }}$ edition, Lawrence Erlbaum Associates, New York, 1988.

29. T.W. Anderson, "An introduction to multivariate statistical analysis" $3^{\text {rd }}$ edition, John Wiley and Sons, Hoboken, New Jersey, 2003.

30. H.F. Kaiser, Educ. Psychol. Meas., 1960, 20, 141-151.

31. S.R. Imadim, S. Wasee, A.G. Kazi, M.M. Azooz, P. Ahmad, "Aluminum toxicity in plants" An overview. In: Ahmad, P. (Ed.): Plant metal interactions, $1^{\text {st }}$ edition, Elsevier Inc, Amsterdam, 2016, pp. 1-20.

32. R. Hajiboland, S. Bahrami-Rad, J. Barcelo, C. Poschenrieder, J. Plant Nutr. Soil Sc., 2013, 176, 616-625.

33. A. Azizi, F. Yan, B. Honermeier, Ind. Crops Prod., 2009, 29(2/3), 554-561.

34. R. Reeves, NATO Science Series IV: Earth Environmental Sciences, 2006, 68, 25.

35. J.L. Todoli, L. Gras, V. Hernandis, J. Mora, J. Anal. Atomic Spectrom., 2002, 17(2), 142-169.

36. M.L. Salit, G.C. Turk, A.P. Lindstrum, T.A. Butler, C.M. Beck, B. Norman, Anal. Chem., 2001, 73(20), 4821-4829.

37. K.E. Sharpless, J.B. Thomas, S.J. Christopher, R.R. Greenberg, L.C. Sander, M.M. Schantz, M.J. Welch, S.A. Wise, Anal. Bioanal. Chem., 2007, 389(1),171178.

38. I.T. Jolliffe, J. Cadima, Philos. T.R. Soc. A, 2016, 374:20150202.

39. F. Zolfaghari, H. Khosravi, A. Shahriyari, M. Jabbari, A. Abolhasani, PLoS one, 2019, 14(12), e0226355. 